\title{
Results of the Management of Urogenital Fistulae from Community Caravans
}

\author{
Eric Bohoussou', Jean Marc Dia ${ }^{1 *}$, Gerard Okon'1, Lydie Djanhan ${ }^{3}$, Bilé Kouamé2, Yao Djanhan ${ }^{3}$, \\ Gabriel Gnanazan", Serges Boni ${ }^{5}$
}

${ }^{1}$ Department of Gynecology and Obstetrics, University and Hospital Center of Treichville (CHUT), Abidjan, Cote d'Ivoire ${ }^{2}$ National Coordinator Fistula Project, UNFPA, Abidjan, Cote d'Ivoire

${ }^{3}$ Department of Gynecology and Obstetrics, University and Hospital Center of Bouaké (CHUB), Bouaké, Cote d'Ivoire ${ }^{4}$ Department of Urology, University and Hospital Center of Treichville (CHUT), Abidjan, Cote d'Ivoire

${ }^{5}$ Department of Gynecology and Obstetrics, University and Hospital Center of Cocody (CHUC), Abidjan, Cote d'Ivoire

Email: *jmlaminedia@yahoo.fr

How to cite this paper: Bohoussou, E., Dia, J.M., Okon, G., Djanhan, L., Kouamé, B., Djanhan, Y., Gnanazan, G. and Boni, S. (2017) Results of the Management of Urogenital Fistulae from Community Caravans. Open Journal of Obstetrics and Gynecology, 7, 858865.

https://doi.org/10.4236/ojog.2017.78086

Received: May 29, 2017

Accepted: July 31, 2017

Published: August 3, 2017

Copyright $\odot 2017$ by authors and Scientific Research Publishing Inc. This work is licensed under the Creative Commons Attribution International License (CC BY 4.0).

http://creativecommons.org/licenses/by/4.0/

\begin{abstract}
Objective: To report the experience of surgical caravans for urogenital fistulas care. Methodology: This was a retrospective study covering the period from January 2014 to December 2014 and which took place on 7 sites of fistula care. The epidemiological, anatomoclinical, therapeutic and evolutionary aspects were studied. Results: 346 patients were operated during 14 caravans. Their average age was 33.11 years (range: 12 to 70 years). Most of these patients were without remunerative activities (80\%) and without education (63.3\%). The average duration of fistula progression was 6.08 years (range: 0 to 42 years). Obstetrical etiology was predominant (87.9\%). According to the classification of Kees Waaldijk, fistulas were divided into type I (67.4\%), type II (21.1\%), and type III (11.5\%). The most common surgical approach was the transvaginal route $(82.1 \%)$. The vesicovaginal splitting with separated suture of the bladder and the vagina was the basic technique (94.7\%). The therapeutic results were judged after a follow-up of 1 month and 3 months. Across the cohort, 80 patients $(23.1 \%)$ were lost of sight for follow-up at 1 month and $245(70 \%)$ at 3 months. The success rates evaluated in patients reviewed at 1 month and 3 months were respectively $70 \%$ and $64 \%$. Conclusion: The incidence of urogenital fistulas is still high in Côte d'Ivoire. Various anatomoclinical varieties have been identified and treated with satisfactory results in poorly equipped local structures.
\end{abstract}

\section{Keywords}

Urogenital Fistulas, Epidemiology, Diagnosis, Treatment 


\section{Introduction}

Uro-genital fistulas (UGF) are a solution of continuity between the urinary and genital tracts in women [1] [2]. In developing countries, the social exclusion they create, as well as the unsufficient provision of care linked in part to the lack of local expertise, have dramatic physical and psychosocial consequences for the patients-mostly very young-affected with UGF [2] [3]. In Côte d'Ivoire, the management of the UGF was done in specialized departments of the University Hospital Centers, which are difficult to access for these poor and rural patients [4] [5]. In order to widen the provision of care, the Ivorian authorities, since 2007 with the support of the United Nations Population Fund (UNFPA), have launched free local surgical caravans in rural areas. These caravans also help to train health professionals and provide the regions visited with technical equipment for the care and repair of UGF. The purpose of this work is to report the experience of these surgical caravans.

\section{Methodology}

This was a descriptive, retrospective study of a cohort of patients carriers of UGF operated during surgical caravans of 10 days between $1^{\text {st }}$ January 2014 and $31^{\text {st }}$ December 2014. These caravans were held in 7 care sites erected by the Ministry of Public Health in collaboration with the UNFPA. These sites were located within existing hospital structures, namely the University Hospital Center of Bouaké, and the Regional Hospital Centers of Bondoukou, Man, Gagnoa, Séguéla, Korhogo and San Pédro (Figure 1).

The care of the patients during each caravan was composed of:

- A mobile team of three trainers: an expert surgeon of the Fistula project and two university professors (urologists and gynecologists-obstetricians);

- Professionals to be trained (Gynecologists-obstetricians, surgeons, nursing specialists and midwives) from the visited site ("local team") and other health regions.

Patients were pre-selected by local surgical teams and then assessed by the entire caravan team.

The preoperative evaluation included a complete clinical examination, urogynecological examination using valves with or without methylene blue to determine the site of the fistula. No paraclinic diagnostic tests were performed.

The variables studied were socio-demographic, clinical, therapeutic and evolutionary. On the clinical side, we used the classification of Kees Waaldijk [6]. It distinguishes 3 types of UGF:

- Type 1 or simple vesico-vaginal fistula (VVF): located at a distance from the bladder neck that does not touch the sphincter;

- Type 2 or VVF with lesion of the sphincter:

- Type 2a or complex VVF: does not completely destroy the urethra

- Type $2 \mathrm{~b}$ or severe VVF: total lesion of the urethra

- Type 3: other including combined forms.

The post-operative follow-up was carried out by the local medical team. The- 


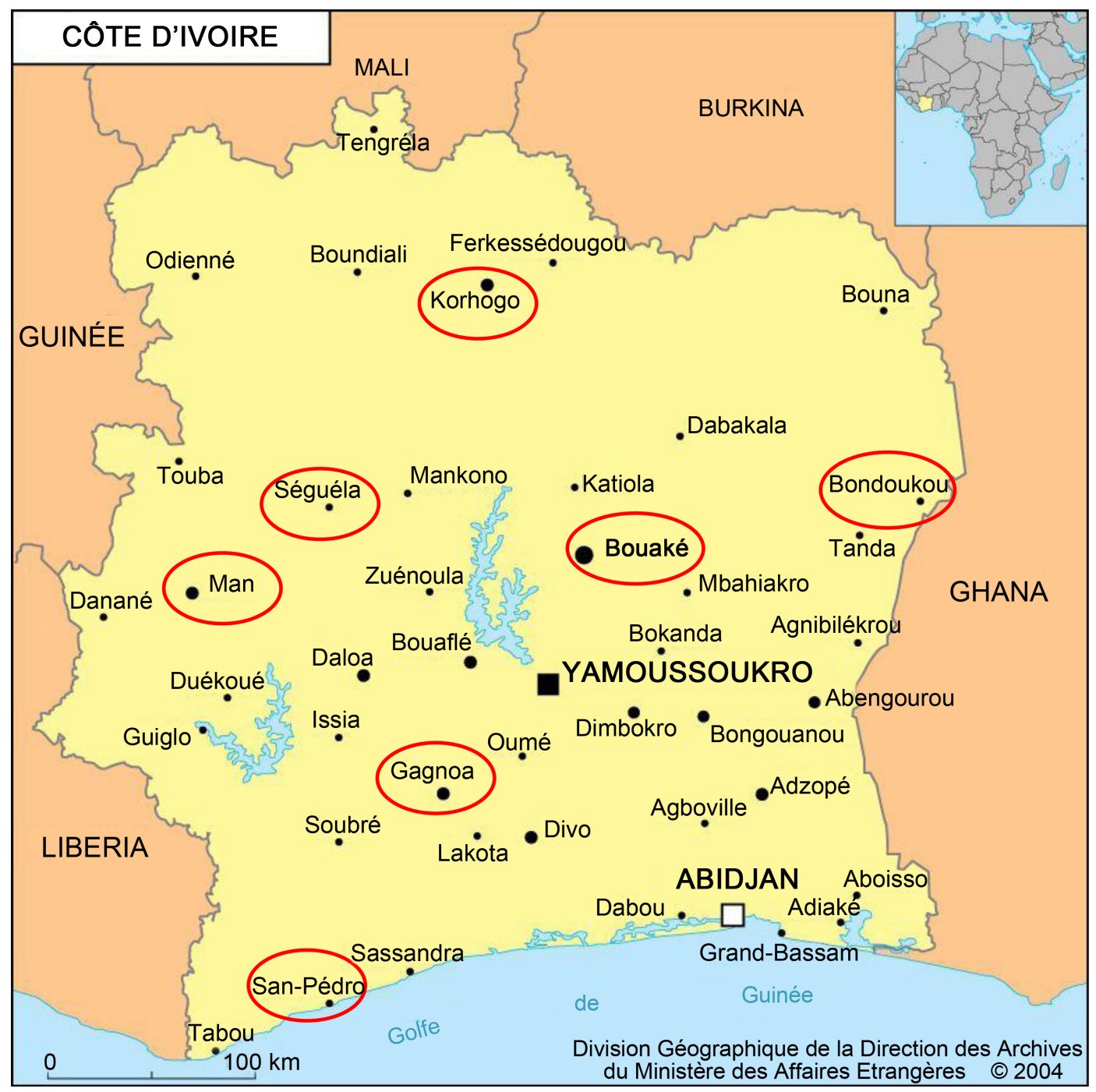

Figure 1. Map of Cote d'Ivoire representing the caravan sites of management.

rapeutic results were assessed after 1 month and 3 months follow-up.

All patients with closed fistula (dry patients) with no sphincter disorders or urinary incontinence were cured.

\section{Results}

\subsection{Epidemiological Characteristics}

During the study period, 346 patients affected with fistula were operated in 14 caravans, an average of 24.8 patients (range: 14 and 34) per caravan. Their average age was 33.11 (range: 12 - 70 years). The majority (73.4\%) lived in rural areas. Illiterates and housewives accounted for 63.3\% $(\mathrm{n}=219)$ and $80 \%(\mathrm{n}=$ 277 ) of the cohort $49.1 \%$ of the patients were divorced or abandoned by their families. One hundred and forty-five patients (41.9\%) were residing in the host city of the caravan. The other 201 (58.1\%) had to travel an average of $192 \mathrm{~km}$ (extremes: 39 and $696 \mathrm{~km}$ ) from their place of residence to access the caravan 
site.

\subsection{Clinical Characteristics}

The average duration of fistula progression was 6.08 years (range: 0 to 42 years). Fistula has been evolving for more than 10 years in 265 patients (76.6\%). 245 patients $(70.8 \%)$ had no prior treatment. The etiology of the fistula was obstetricin 304 patients (Table 1). The average duration of labor was 2.3 days (range $0-5$ days) and had a low vaginal delivery in $31.9 \%$, caesarean section in $62.2 \%$ and hysterectomy in $5.9 \%$.

- Origin of the fistula

- Classification of the fistulae

Table 2 gives the type of UGF according to the Kees Waaldijk classification. The average fistula size was $1.2 \mathrm{~cm}$ (range: $0.1-6 \mathrm{~cm}$ ).

\subsection{Therapeutic Characteristics}

At the therapeutic level, spinal anesthesia was performed in 329 patients (95.10\%). The surgical route was vaginal in $82.1 \%$ of cases (284 patients), abdominal in $11.6 \%$ of cases ( 40 patients) and mixed in $6.3 \%$ of cases ( 22 patients). The vesico-vaginal splitting with suture separated from the bladder and vagina was the basic technique (94.7\%; $\mathrm{n}=328$ ); 25 patients had a colposuspension. In 18 patients (5.3\%), an exclusive ureteral reimplantation was performed to treat uretero-vaginal fistulae.

The average urinary catheter ablation time was 27.27 days (range: $14-30$ days).

Of the total cohort, $80(23.1 \%)$ patients were lost of sight to follow-up at 1 month and $245(70 \%)$ at 3 months. The cure rates evaluated in patients reviewed at 1 month and 3 months were respectively $70 \%$ and $64 \%$. Figure 2 shows the operative results according to the type of fistula at 1 month.

\section{Discussion}

\subsection{Epidemiological Characteristics}

The cohort of this study was composed of 346 fistula patients operated in one

Table 1. Distribution of patients according to the etiology of the fistula.

\begin{tabular}{ccc}
\hline Etiologies of fistulae & Population & Percentage (\%) \\
\hline -ObstetricFistulae & 304 & 87.9 \\
-Non obstericFistulae & 38 & \\
- Surgical & 2 & 10.9 \\
-Complications of FGM & 2 & 0.6 \\
-Sexual agression & 346 & 0.6 \\
Total & & 100 \\
\hline
\end{tabular}

*FGM: female genital mutilation. 
Table 2. Distribution of UGF as classified by Kees Waaldijk [6].

\begin{tabular}{ccc}
\hline Types of fistula & Population & Percentage (\%) \\
\hline Type I & 233 & 67.4 \\
Type II & 73 & 21.1 \\
Type III & 40 & 11.5 \\
Total & 346 & 100 \\
\hline
\end{tabular}

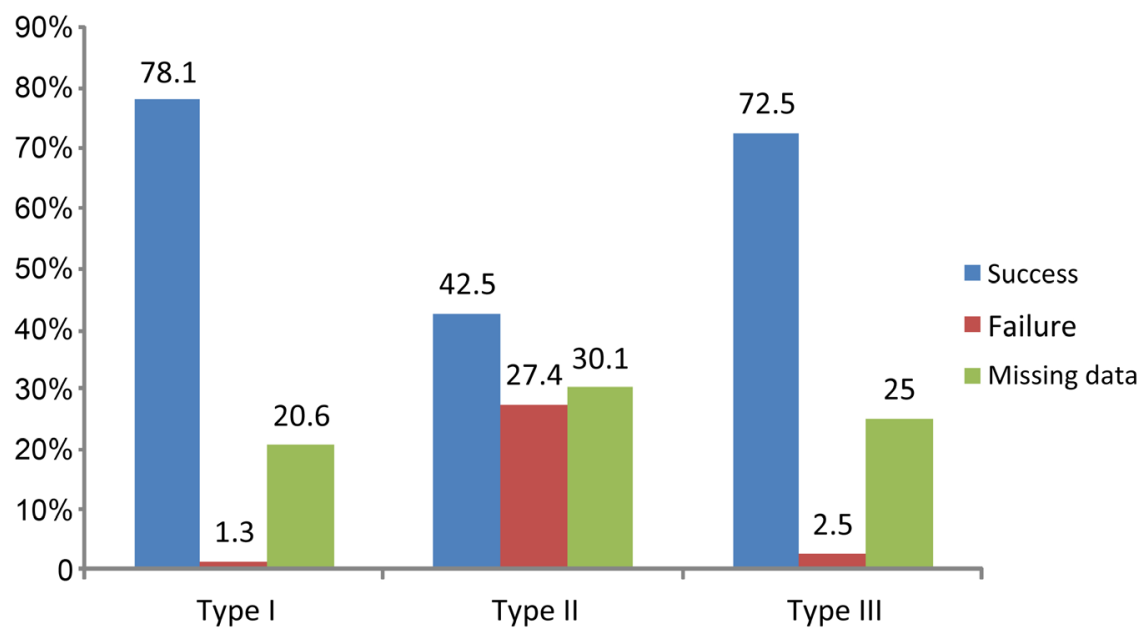

Figure 2. Results according to the type of fistula at 1 month post operative.

year in seven towns (Figure 1). These figures, which appear to be high, are not very representative of the real needs to be met in terms of repairing UGF in the subregion countries in general. Indeed in these countries which already had the experience of the fistula caravan, many fistula patients are not treated at every caravan either for lack of information or difficulties to access to the caravan site [7] [8] [9]. The surgical caravans have had the merit of widening the provision of care. Therefore they must be perpetuated and above all extended to all the regions of Côte d'Ivoire. However, they must quickly give way to the establishment of permanent services able to manage a greater number of fistula patients [10]. However, the biggest challenge remains the active identification of the many fistula patients living in the community who are hiding and who are unaware of the existence of treatment [1] [8] [11]. They should be informed of thehealing possibilities and directed towards the care sites. A large-scale awareness of policy makers, health professionals, non-governmental organizations, religious and community leaders would make it possible to find one large number.

Regarding the epidemiological profile of the fistula patients found in the series, it was not different from that reported by most African authors [2] [7] [8] [12] [13] [14]. They were young, poor, uneducated, residing in rural areas and abandoned by their spouses or their entourage.

\subsection{Diagnostic Characteristics}

The majority of the patients of this study had a fistula which evolved over 10 
years $(76.6 \%)$, and $70.8 \%$ of cases didn't received any care. This observation shows the importance of uncovered needs for fistula repair in Côte d'Ivoire.

As for the occurrence mechanism, obstetric factors were the main causes $(87.9 \%)$ of the cases we had cared for (Table 1 ). Many authors have also reported that obstetric factors were the main causes of fistula (around 90\%) in developing countries because of the difficulties to access to emergency obstetric care [2] [7] [8] [11] [12] [13] [14] [15].

According to the seriousness, Table 2 shows that complex fistulae were common in the study series $(21.1 \%)$ and many african authors also described these complex forms in their articles [2] [8] [12].

Moreover $67.4 \%$ of simple fistulae were found in this study (Table 2) which could be linked to selection bias. Indeed, the punctual nature of the caravans and the lack of equipment at the sites proved to be unsuitable for the management of complex forms requiring more means, more important surgery and prolonged follow-up.

\subsection{Therapeutic Characteristics}

The majority of fistulas $(82.1 \%)$ were surgically accessible through vaginal route and spinal anesthesia (95.10\%) was the most common type of anesthesia which permitted to minimize the cost of care. The most performed surgical technique was the vesicovaginal splitting with separated suture of the bladder and the vagina, without the addition of neighborhood structure (Figure 2). This technique was carried out on fistulous orifices of size varying between 0.1 and $6 \mathrm{~cm}$. It has also been performed by Wall and Dekou when the orifices had a diameter of between 0.2 and $8 \mathrm{~cm}$ [16] [17]. Therapeutic results were judged after one month and three months follow-up. They are characterized by a significant number of lost of sight. These facts point to another challenge in evaluating therapeutic outcomes: the difficulty of monitoring the patients undergoing surgery. At 1 month the results were characterized by a high rate of failure in type II fistulas and a 70\% success rate in types I and III, and were consistent with data from the literature [15] [18] [19]. The care of type II fistulae is marked by a high rate of failure in relation to post-cure urinary incontinence even when sealing is achieved [10] [12] [18] [19]. Different techniques are proposed to treat post fistula urinary incontinence [14] [18] [19]. Among these techniques, we performed colposuspension (25 cases), described by Waaldijk [6]. Although these techniques seem to produce interesting results, it is difficult to draw conclusions from this because of the difficult follow-up of patients over a long term [18] [19]. Moreover, the high cost of synthetic strips makes it impossible to afford them in developing countries [18].

\section{Conclusion}

This study showed that the incidence of urogenital fistula in our country is underestimated. They are mostly of obstetric origin and their diagnosis was essen- 
tially clinical. Various anatomo-clinical varieties were identified. The majority was treated by the vesicovaginal splitting with separated suture of the bladder and the vagina, with satisfactory results in poorly equipped local structures. Therefore, the UNFPA's policy aiming to reinforce capacities of health professionals for the treatment of UGF should be perpetuated.

\section{References}

[1] Anoukoum, T., Attipou, K.K., Agoda-Koussema, Akpadza, K. and Ayité, E.A. (2010) Epidemiological, Aetiological and Treatment Aspects of Obstetrical Fistula in Togo. Progrès en Urologie, 20, 71-76. https://doi.org/10.1016/j.purol.2009.08.038

[2] Kaboré, A.F., Kambou, T., Ouattara, A., Zango, B., Yaméogo, C., Kirakoya, B., et al. (2014) Epidemiology, Etiology and Psychosocial Impact of Urogenital Fistulas in a Cohort of 170 Consecutive Patients Managed in Three Treatment Centers in Burk in a Fasofrom. Progrès en Urologie, 24, 526-532.

[3] Schlienger, G., Laroche, J., Karsenty, G., Bertrand, S., Dulac, J.P., Fournier, R., et al. (2012) Obstetrical Vesicovaginal Fistula for Single Visiting Surgeons in Africa. $\mathrm{Me}$ decine et Sante Tropicales, 22, 126-130.

[4] Le Guyader, A., Yao-Djè, C. and Djédjé-Mady, A., et al. (1979) A Propos de 696 Fistules Uro-Génitales Opérées par le Même Chirurgien: de L'Intérêt de la Recto-Myoplastie. Chirurgie, 105, 854-859.

[5] Yao, B., Gnagne, M., Sery, F., Dossou, C. and Gnanazan, G. (2003) Treatment of Vesicovaginal Fistulas Using the Musculofascial Flap of the Levator Ani Muscle: 26 Case Reports. Urology Annals, 37, 108-112. https://doi.org/10.1016/S0003-4401(03)00043-3

[6] Waaldijk, K. (1994) Step by Step Surgery of Vesico-Vaginal Fistulas. Campion Press, Edenburg, 21-29.

[7] Diarra, A., Tembely, A., Berthe, H.J., Diakité, M.L., Traoré, B. and Ouattara, K. (2013) Social Integration of Women Operated for Obstetric Urogenital Fistula. Progrès en Urologie, 23, 1000-1003. https://doi.org/10.1016/j.purol.2013.04.013

[8] Konan, P.G., Dekou, A.H., Gowé, E.E., Vodi, C.C., Fofana, A., Kramo, N., et al. (2015) Evolution Aspect of Anatomy Clinical Lesions of Urogenital Fistula (UGF) in Cocody Teaching Hospital Urologi Calunity from 1990 to 2011. Progrès en Urologie, 25, 474-481. https://doi.org/10.1016/j.purol.2015.03.002

[9] Ndiaye, P., Amoul, K.G., Idissa, A., Diagne, C.M. and Tal-Dia, A. (2009) Parcours de la femme souffrant de fistule obstétricale au Niger. Médecine Tropicale, 69, 61-65.

[10] De Bernis, L. and Slinger, G. (2011) Fistule obstétricale : comment accélérer l'accès à la prévention, la réparation, et assurer une bonne réintégration socio-économique? Mises à Jour en Gynécologie-Obstétrique et Techniques Chirurgicales. Collège National des Gynécologues et Obstétriciens Français, Paris, 579-597.

[11] Somé, D.A., Zalha, A., Ouédraogo, I., Ouattara, A., Zaré, C., Ouattara, S., et al. (2014) Management of Obstetric Fistulae in a Level 2 Hospital in Burkina Faso. Annales de la SOGGO, 23, 95-100.

[12] Diallo, A.B., Sy, T., Bah, M.D., Diallo, T.M., Barry, M.S., Bah, I., et al. (2016) Obstetrical Vesico-Vaginal Fistula in Guinea: Data Analysis of Three Sites of Treatment at Engender Health ONG. Progrès en Urologie, 26, 145-151. https://doi.org/10.1016/j.purol.2016.01.006 
[13] Guèye, S.M., Diagne, B.A. and Mensah, A. (1992) Les fistules vésico-vaginales: aspects étio-pathogéniques et thérapeutiques au Sénégal. Medecine d'Afrique noire, 39, 559-563.

[14] Kimassoum, R., Franklin, D.S., Arya, Z.A.T. and Kaboro, M. (2016) Evaluation of Urinary Incontinence Treatment after Obstetric Fistula Cure. Uro-Andro-Med, 1, 242-246.

[15] Moudouni, S., Nouri, M., Koutani, A., Ibn Attya, A., Hachimi, M. and Lakrissa, A. (2001) Obstetric Vesico-Vaginal Fistulas. A Series of 114 Cases. Progrès en Urologie, 11, 103-108.

[16] Wall, L.L. (2006) Obstetric Vesicovaginal Fistula as an International Public-Health Problem. Lancet, 368, 1201-1209. https://doi.org/10.1016/S0140-6736(06)69476-2

[17] Dékou, A.H., Konan, P.G., Manzan, K., Ouegnin, G.A., Djédjé-Mady, A., Yao-Djè, C. (2002) Le point sur les fistules urogénitales en Côte d'Ivoire à la fin du XXéme siècle. Résultats de 70 cas. Uro-Andro-Med, 36, 334-340.

[18] Browning, A. (2006) Risk Factors for Developing Residual Urinary Incontinence after Obstetric Fistula Repair. BJOG, 113, 482-485. https://doi.org/10.1111/j.1471-0528.2006.00875.x

[19] Colas, J.M. and Blanchot, J. (2009) Incontinence urinaire après réparation de fistule vésico-vaginale. Mises à Jour en Gynécologie-Obstétrique et Techniques Chirurgicales. Collège National des Gynécologues et Obstétriciens Français, Paris, 583-589.

\section{Submit or recommend next manuscript to SCIRP and we will provide best} service for you:

Accepting pre-submission inquiries through Email, Facebook, LinkedIn, Twitter, etc. A wide selection of journals (inclusive of 9 subjects, more than 200 journals)

Providing 24-hour high-quality service

User-friendly online submission system

Fair and swift peer-review system

Efficient typesetting and proofreading procedure

Display of the result of downloads and visits, as well as the number of cited articles

Maximum dissemination of your research work

Submit your manuscript at: http://papersubmission.scirp.org/

Or contact ojog@scirp.org 